\title{
MODELS OF APPROACHES TO DIGITAL COMPETENCES
}

Michal $\check{C} \boldsymbol{E R N} \boldsymbol{Y}^{*}$, Masarykova univerzita v Brně, Česká republika

Přijato: 6. 7. 2020 / Akceptováno: 1. 10. 2020

Typ článku: Přehledová studie

DOI: $10.5507 /$ jtie.2020.019

Abstract: The review study analyzes 15 papers from the SCOPUS database, which deal with the issue of digital competences in the field of education. Based on this analysis, it offers a basic view of both the research field itself and the topics described in these articles. They show that, although the issue is current and socially relevant, it is still not given due attention in the field of educationneither researching nor theoretically. At the same time, the review study points to some broader issues of competence research as such.

Key words: digital competences, models of digital competencies, research of digital competences, overview study

\section{MODELY DIGITÁLNÍCH KOMPETENCÍ}

Abstrakt: Přehledová studie analyzuje 15 článků z databáze SCOPUS, které se věnuji problematice digitálních kompetencí v oblasti vzdělávání. Na základě této analýzy nabizi základni pohled jak na vlastni výzkumné pole, tak na témata, která tyto články popisuji. Ukazuji, že jakkoli jde o téma aktuální a společensky závažné, v oblasti vzdělávání mu stále není věnována náležitá pozornost. A to ani výzkumně, ani teoreticky. Přehledová studie současně poukazuje na některé širší problémy výzkumu kompetencí jako takových.

Klíčová slova: digitální kompetence, modely digitálních kompetencí, výzkumy digitálních kompetencí, přehledová studie.

\footnotetext{
*Autor pro korespondenci: mcerny@phil.muni.cz
} 


\section{1 Úvod}

Digitální kompetence jsou tématem, o kterém se hovoří jak ve veřejném prostoru, tak také voblasti univerzitního vzdělávání, transformace kurikula nebo ve vztahu k akademickým dovednostem (Yazon et al. 2019) či pracovnímu trhu (Siddoo 2017). Přesto se ukazuje, že jde o téma stále poměrně nejasně výzkumně i teoreticky ukotvené. Cílem námi provedené přehledové studie bude nabídnout pohled na problematiku modelů digitálních kompetencí optikou studií zařazených do databáze SCOPUS. V souvislosti s nutností realizovat alespoň část výuky online během pandemie COVID-19 se toto téma stalo ještě důležitějším. (Leigh et al. 2020, Longhurst et al. 2020, Johnson et al. 2020)

Nabídnout jednoduchou a jasnou odpověd' na to, co by to mohly být digitální kompetence, je náročné. Literatura, jak odborná, tak i popularizační, je v tomto ohledu nejednotná. Současně jde o téma, které má jednoznačně velkou časovou proměnlivost. Ta působí, že pět a více let staré texty mohou trpět významovým posunem, který pro konkrétní praxi může být fatální.

Druhým problémem je, že v češtině operujeme s pojmem kompetence. Ten má ale v angličtině dva překlady, jejichž význam je ale (většinou) odlišitelný, takže může docházet k jistému matení toho, co vlastně daná studie reflektuje.

Pro metodologii vyhledávání studií je důležité upozornit na tuto pojmovou dvojznačnost. Teodorescu (2006), uvádí, že:

Competency models - obsahuje soubor doporučení pro jednání, dovednosti, znalosti či postoje pro každou jednotlivou roli ve společnosti. Jednotlivé znalosti, dovednosti, postoje jsou zachyceny výčtem a mohou být strukturovány dle důležitosti. Mohou být spojené s kurikulem nebo např́klad s požadavky na určitou pracovní pozici.

Competence models - je rámcem popisující procesní a pracovní výsledky, které jsou nezbytné pro dosažení stanovených cílů pro určité role, týmy nebo celé organizace. Jednotlivé požadavky (,,složky kompetence“) jsou jednoznačně spojené se situacemi, které musí daný jedinec nebo instituce zvládnout pro úspěšné plnění svých cílů. Jsou spojené se zaměřením na schopnost plnit určitý úkol, pokud možno trvale. Nemají atomický charakter, ale jsou šířeji orientované.

Nejde pochopitelně o jediné nebo ideální vymezení kompetenčních modelů, ale ukazuje, že je zde jazykový úzus, který se do češtiny částečně transformoval jako spor o to, zda existuje jedna kompetence nebo je kompetencí více (často se hovoří o trsech kompetencí). To ale nebude předmětem našeho zájmu. S ohledem na diskuse, které provádíme $\mathrm{v}$ některých dalších studiích, se nebudeme snažit ani vymezit pojem kompetence $\mathrm{v}$ úvodu naší přehledové studie.

Kompetencím budeme $\mathrm{v}$ naší studii rozumět poměrně volně $\mathrm{s}$ Veteškou a Tureckiovou (2008, s. 25), kteří tvrdí, že kompetence je: „Specifický soubor znalostí dovedností, zkušenostní metod a postupů, ale také například postojů, které jednotlivec využívá k úspěšnému řešení nejrůznějších životních situací a úkolů a jenž mu umožňují osobní rozvoj i naplnění jeho životních aspirací. "Spojují tedy oba výše uvedené anglické pojmy do jedné definice užívajíce spojky ale i. Gramotnost je pak schopnost aktivně participovat na světě informací, (Dombrovská 2001, s. 23, Pavelková et al., 2012, Dombrovská et al. 2004, s. 109) tedy aktualizovaná potence kompetence. Gramotnost je žitým projevem kompetence.

Zřejmě nejznámějšími modely jsou ty, které vycházejí z JRC: European Research Council, jež stojí za modelem Evropského rámce digitálních kompetencí pro občana (Carrater et al. 2017) (aktuálně ve verzi 2.1), vychází z metastudie a metaanalýzy různých 
textů, vztahujících se právě $\mathrm{k}$ digitálním kompetencím. Jeho specifikem je poměrně jasný humanistický rámec, který pracuje s představou občana jako aktivního prvku v konstituci společnosti. Např́klad na úroveň 5 a výše (z 8) je možné se dostat jen tehdy, pokud je člověk schopen aktivně pomáhat druhým. Tento model solidarity není zcela samozřejmý a v chápání toho, co je a není digitální kompetence, může být velice specifický. Tento rámec má také své odvozeniny pro konkrétní cílové skupiny. Lze se tak setkat s jeho verzí pro učitele (DigComp Edu), digitálně fungující vzdělávací organizace (DigComp Org) nebo pro spotřebitele (DigCompConsumers).

Druhým tradičně užívaným modelem je tzv. ,řidičák na počítač“ - ECDL respektive ICDL (Borgman et al. 2003, Calzarossa et al. 2007). Ten vychází především z požadavků firem a do jisté míry reflektuje dovednosti a znalosti, které musí mít administrativní pracovník. Vznikl jako reakce na situaci, kdy digitalizaci firem bránily nízké digitální kompetence, které se snažil právě tento mezinárodní certifikát (a s ním spojený kompetenční rámec) jak pojmenovat, tak také je rozvíjet a testovat. Slabinou rámce je jeho jednostrannost a zaměření na poptávku trhu, výhodou snadná uchopitelnost a testovatelnost.

\section{Metodologie}

V rámci naší přehledové studie jsme nechtěli dopředu stanovit ani cestu competency ani competence. Současně s ohledem na literaturu jsme se rozhodli vyhledávat jak models tak také framework, nebot' oba pojmy se mohou použít pro to, co v češtině překládáme jako kompetenční model.

Pro vyhledávání jsme využili databázi SCOPUS s následujícím vyhledávacím dotazem:

TITLE-ABS-KEY ( ( "Digital Competency model" OR "Digital Competence models") OR ( "Digital Competency framework" OR "Digital Competence framework" ) )

Ten nám poskytl celkem 28 výsledků, které $\mathrm{v}$ další části přehledové studie budeme analyzovat. K vyhledávání došlo 26. 6. 2020. Ze seznamu jsme dále vyřadili kapitoly v monografiích, nebot' nás zajímal jen ucelený výstup.

Pokud se podíváme na analýzu výsledků po letech, můžeme vidět stoupající trend v roce 2019 šlo o 9 dokumentů, 2017 o 5 a 2015 o 1 dokument. $Z$ hlediska místa publikování je nejaktivnější Španělsko (7), následované Thajskem (3), Malajsií, Norskem a Velkou Británií (po 2). 18 dokumentů pochází z časopisů, dalších 7 je konferenčních statí a 2 jsou kapitoly v knize. Jeden text pak měl př́znak Review.

Pokud se podíváme na analýzu klíčových slov, tak z korpusu 28 výsledků můžeme rríci, že nejčastějšími jsou:

\begin{tabular}{|l|r|}
\hline Klíčové slovo & Výskyt \\
\hline Digital Competence & 16 \\
\hline Digital Literacy & 4 \\
\hline Digital Technologies, E-learning, Students, Education & 3 \\
\hline Certification, Competence Models, Computers, Computer Science, & 2 \\
Digital Competences, Digital Competency, Digital Literacies, Digital & \\
\hline
\end{tabular}


Skills, Digital Society, Digital Technology, Higher Education, Teacher Training, Teachers, Teaching, Technology Enhanced Learning

Tab. č. 1: Tabulka nejčastéjšich klíčových slov v nalezeném souboru dokumentůdata dle SCOPUS.

Jen pohled na klíčová slova již odkrývá první důležitá zjištění - texty pracují vlastně rovnoměrně s pojmy Competency, Competence, ale i Skills či Literacies. Nemusí nutně jít o to, že by je studie nerozlišovaly, ale data jasně ukazují, že všechny čtyři pojmové dimenze dané problematiky jsou vnímané jako podobně významné. Vyšší výskyt mají Digital Literacy v jednotném čísle. Zde je důležité upozornit, že např́ílad Evropský rámec digitálních kompetencí pro občany (DigComp 2.1) mezi těmito pojmy nediferencuje také a vyhýbá se jejich definování. Jakkoli vnímáme, že pro pedagogickou veřejnost existuje rozdíl mezi kompetencí a gramotností (či dokonce pouhou dovedností), analyzovaný korpus dokumentů ukazuje, že nejde o dělení zásadní.

Druhým zajímavým zjištěním $\mathrm{z}$ analýzy klíčových pojmů je zaměření digitálních kompetencí na učitele a edukační proces. Tuto hypotézu bude nutné prověřit ještě studiem obsahu jednotlivých textů, ale zdá se být pravděpodobné, že je to právě široce uchopené školní prostředí, na které se práce s modely digitálních kompetencí zaměřují.

\section{Výsledky}

Níže uvádíme stručný popis analyzovaných studií. Na tomto místě se soustředíme na relevantní zjištění pro kontext naší přehledové studie. V prř́loze textu je k dispozici tabulka, která shrnuje níže uvedené studie a popisuje jejich vybrané parametry (druh studie, výzkumné metody, klíčová zjištění, zemi původu, citační ohlasy).

Krumsvik, R. J. (2014). Teacher educators' digital competence. Scandinavian Journal of Educational Research, 58(3), 269-280.

Studie se zaměřuje na problematiku vzdělávání učitelů v Norsku. Upozorňuje, že v roce 2012 si tamní úřady povšimly velkého rozdílu mezi očekávanými a potřebnými digitálními kompetencemi. $\mathrm{O}$ těch se v článku hovoří o jako digital bildung, tedy v jasné návaznosti na německou pedagogickou tradici. Text upozorňuje, že digitální kompetence nejsou pro učitele jen schopnosti ovládat techniku, ale mají širší a významnější dopad na celý způsob jejich didaktického a pedagogického myšlení. Mezi digitální kompetence pro učitele se $\mathrm{v}$ tomto modelu řadí etika $\mathrm{v}$ digitálním prostředí, digitální kompetence vztažené ke strategiím učení, didaktická kompetence ve vztahu k ICT. Významně je akcentován rozměr toho, že učitel musí být vzorem pro studenty i ve schopnosti využívat ICT.

Janssen, J., Stoyanov, S., Ferrari, A., Punie, Y., Pannekeet, K., \& Sloep, P. (2013). Experts' views on digital competence: Commonalities and differences. Computers \& Education, 68, 473-481.

Studie se zaměřuje na mnoho důležitých témat. Upozorňuje na lexikální problém, kdy řada autorů hovoří o digitální gramotnosti, ale ve skandinávském prostředí se preferuje pojem kompetence s důrazem na širší vzdělanostní koncept. Klíčovou otázkou je, zda vůbec můžeme hovořit o čisté digitální kompetenci, která je oddělitelná od ostatních, nebo zda jsou digitální kompetence vždy primárně kompetencemi s určitým širším kotvením (na kompetence $\mathrm{k}$ učení, řešení problémů atp.) . Výsledkem studie je model, který pracuje s určitými tematickými bloky: 1) s kompetencí jako s nástrojem každodennosti; 2) se schopností komunikovat a spolupracovat skrze ICT; 3) se schopností pracovat 
s informacemi; 4) s etickou a legální dimenzí; 5) s jistým sociologickým chápáním digitálních kompetencí a 6) se schopností učit se a rozvíjet se skrze ICT.

Krumsvik, R. J. (2008). Situated learning and teachers' digital competence. Education and Information Technologies, 13(4), 279-290.

Text je v jistém ohledu prŕípravou na studii (Krumsvik 2014). Pracuje v podstatě se stejným modelem, který počítá se čtveřicí dimenzí kompetencí učitele. To, co považujeme za významné v této studii, jsou tři aspekty - tím prvním je neustálé vztahování se ke studentům. Učitel nedisponuje digitálními kompetencemi primárně pro sebe, ale pro studenta a jeho možnost edukace. Za druhé pracuje s pojmem epistemická slepota v kontextu osob, které nemají rozvinuté digitální kompetence. Tento pojem je velice důležitý, odkazuje $\mathrm{k}$ nikoli $\mathrm{k}$ modernímu pojetí nevidomých, ale $\mathrm{k}$ biblickému př́istupu, ve kterém slepota je něčím, co člověka tíží a sociálně vyčleňuje, něco, čeho by se měl sám zbavit, za co sám nese vinu, co narušuje jeho ontologickou kvalitu. V neposlední řadě je zde pak ,digital bildung“ spojený s pobytem v online společnosti, v digitalizované škole, $\mathrm{v}$ těsném kontaktu s druhými.

Napal Fraile, M., Peñalva-Vélez, A., \& Mendióroz Lacambra, A. M. (2018). Development of digital competence in secondary education teachers' training. Education Sciences, 8(3), 104.

Empirická studie, která pracuje se sebehodnocením studentů učitelství v oblasti prírodních a technických věd v oblasti 21 kompetencí DigComp. Data ukázala extrémně nízkou pocitovanou úroveň kompetencí, což jednak souvisí zřejmě s neschopností studentů se vhodně ohodnotit, ale také s tím, že ve Španělsku existuje jen velice omezených prostor pro př́pravu studentů v této oblasti. Zdá se, že to, co studenti skutečně umí, nejsou znalosti a dovednosti školní, ale mimoškolní.

Evangelinos, G., \& Holley, D. (2014, September). A qualitative exploration of the EU digital competence (DIGCOMP) framework: a case study within healthcare education. In International Conference on E-Learning, E-Education, and Online Training (pp. 85-92). Springer, Cham.

Výzkum pracuje s kvalitativními metodami (hermeneuticky orientované rozhovory), které sledovaly osobní individualizované př́stupy $\mathrm{k}$ technologiím. Základní obsahová struktura byla dána starou verzí DigCompu a poměrně zřetelně ukázala, že studenti akcentují význam kompetencí směřujících $\mathrm{k}$ učení, ale i zábavě či práci s informacemi. Akademici se soustředili na práci s informacemi, ve kterých jim technika silně pomáhá. Zajímavé přitom je, že zdravotníci velmi potlačili témata širšího dopadu technologií a více se soustředili jen na to, co jim přinášelo každodenní benefity či možnosti.

Prendes Espinosa, M. P., Gutierrez Porlan, I., \& Martinez Sanchez, F. (2018). Digital competence: a need for university teachers in the 21st century. REDREVISTA DE EDUCACION A DISTANCIA, (56).

Text se věnuje silně specifikům Španělského prostředí. To, co může být pro nás zajímavé je, že na základě empirických dat, a především reflexe současného stavu, vytvárí nový model digitálních kompetencí, založený na pěti dimenzích (technické, informační a komunikační, vzdělávací, sebereflexe a sociální a etické) a třech oblastech aplikace (výuka, výzkum a řízení). $\mathrm{V}$ něm vidí autoři nástroj, který by mohl pomoci univerzitám ve Španělsku lépe připravovat učitele s digitálními kompetencemi. 
Siddoo, V., Sawattawee, J., Janchai, W., \& Yodmongkol, P. (2017). Exploring the competency gap of it students in Thailand: The employers' view of an effective workforce. Journal of Technical Education and Training, 9(2).

Studie se věnuje rozporu mezi ICT dovednostmi tak, jak s nimi pracují univerzity a očekáváním trhu. Jde tedy o text zaměřený silně na praktické a konkrétní požadavky. To, co poměrně jasně vysvítá, je jednak existence hlubokého rozporu mezi oběma aktéry „na trhu práce“ a především skutečnost, že zatímco firmy v Thajsku očekávají digitální domorodce, kteří technologie užívají ve všech dimenzích svého života a príímo je přednášejí do firemní kultury, tak vidění univerzit je podstatně konzervativnější a více „akademické“.

Špernjak, A., \& Šorgo, A. (2018, May). Outlines for science digital competence of elementary school students. In 201841 st International Convention on Information and Communication Technology, Electronics and Microelectronics (MIPRO) (pp. 08250829). IEEE.

Diskusní př́ispěvek si všímá skutečnosti, že digitální kompetence nejsou pro všechny stejné. Specificky pro učitele hovoři o třech rovinách - o obecných digitálních kompetencích, které souvisí s technologiemi a měl by je mít každý člověk a specifických digitálních kompetencích pro učitele, které je možné např́klad fakultě sdílet v pregraduální príípravě. A pak je zde rozměr oborově zakotvených kompetencí, které jsou vázané na konkrétní vědní obory. Autoři se domnívají, že role prírodních věd je zde zcela zásadní. Jednak je nutné, aby učitelé tyto kompetence měli, protože jen tak mohou aktivně participovat na moderní vědě, ale současně se zdá být nezpochybnitelné, že právě učitelé př́rodních věd budou svým studentům intenzivně rozvíjet digitální kompetence. Absence digitálních kompetencí u učitelů (primárně asi př́rodovědných) v libovolné rovině vede k fatálnímu selhávání celého edukačního systému.

Lucas, M., Moreira, A., \& Costa, N. (2017). Quadro europeu de referência para a competência digital: subsídios para a sua compreensão e desenvolvimento. Observatorio (Obs*), 11(4).

Přehledová práce nabízí pohled na konstrukci modelu DigComp a jeho myšlenková východiska. Ta jsou zde poměrně přehledně popsána a dávají dobrý náhled na základní dilemata, která museli tvůrci tohoto rámce řešit. Současně ale zdůrazňuje nutnost propojení rámce s možnostmi standardizovaných srovnávacích měření, úrovně kompetence (faktem je, že skutečně funkční je $v$ současně době jen autoevaluace), změny vzdělávání a př́pravy na pracovní trh. V těchto oblastech, stejně jako ve státních politikách, jsme - podle článku - i po pěti letech stále na začátku (v Portugalsku).

Roushan, G., Holley, D., \& Biggins, D. (2016). The kaleidoscope of voices: An action research approach to informing institutional e-learning policy. Electronic Journal of E-Learning, 14(5), 293-300.

Studie poukazuje na fakt, že zavádění inovací do vzdělávání není dobrovolné, je něčím, co přináší jisté problémy a nejistotu a pocit ohrožení. Pokud má docházet ke skutečně efektivnímu zavádění inovací, je třeba hledat koncensus, spolupráci „středu“ (tedy akcentovat situaci meianstreamu) a naslouchat všem zúčastněným. Výsledek akčního výzkumu je TEL Manifesto, který uvádí následujících pět bodů: 1) jsou nutné pedagogické inovace; 2) je třeba hodnotit proces učení; 3) je nutné rozvíjet kompetence pro efektivní učení; 4) pro efektivní učení je nutné nabídnout adekvátní nástroje; 5) zajistit dostupné zdroje. 
Pérez-Escoda, A. (2014, October). Digital competence's frameworks in Europe: an approaching to Spanish and Norwegian framework. In Proceedings of the Second International Conference on Technological Ecosystems for Enhancing Multiculturality (pp. 469-474).

Studie (nebo spíše esej) se snaží komparovat tři modely práce s digitálními kompetencemi - DigComp, Španělský (již výše zmiňovaný) a Krumsvikův, které se snaží zaměřit se na vzdělávání učitelů. Text je silně zakotven ve španělském prostředí a ukazuje, že jakkoli v dílčích parametrech může být norské a španělské IT vybavení podobné, existují zde značné rozdíly v míře digitálních kompetencí. Autor doporučuje klást akcent na státní vzdělávací politiku, jako na klíč k možným změnám.

Yazon, A., Ang-Manaig, K., Buama, C. A. C., \& Tesoro, J. F. B. (2019). Digital literacy, digital competence and research productivity of educators. Universal Journal of Educational Research, 7(8), 1734-1743.

Empirická studie výchozí ze sebehodnocení založeném na DigCompEdu a ptá se, zda existuje spojitost mezi vědeckou (publikační) prací a digitálními kompetencemi. Zdá se, že schopnost pracovat $\mathrm{s}$ informacemi, jejich vyhledávání, tř́ídění, organizace, ale i další činnosti jsou pro akademický výkon statisticky významně důležité. University by se tedy měly snažit tyto kompetence u akademiků rozvíjet.

Köhler, T., Wollersheim, H. W., \& Igel, C. (2019, July). Scenarios of Technology Enhanced Learning (TEL) and Technology Enhanced Teaching (TET) in Academic Education A Forecast for the Next Decade and its Consequences for Teaching Staff. In 2019 8th International Congress on Advanced Applied Informatics (IIAI-AAI) (pp. 240-245). IEEE.

Studie popisuje čtyři možné základní scénáře výuky na vysokých školách a analyzuje dopady, které bude volba daného scénáře mít na učitele. Tuto svoji analýzu pak rámuje úvahami nad tím, do jaké míry je DigCompEdu pro daný koncept funkční. Možné scénáře volí následovně: 1) Klasické analogové učení a výuka; 2) Plně digitální / virtuální učení; 3) Elektronické zkoušky na vyžádání a individuální př́iležitosti k učení; 4) Otevřené vzdělávací zdroje + otevřené vědecko-neformální učení využívající nabídky několika univerzit na základě systémů doporučení. Autoři nemohli reflektovat situaci v souvislostí s COVID-19 a je otázkou, ke kterému scénáŕi by se přiklonili nyní. Je ale zřejmé, že $\mathrm{s}$ rostoucím pořadovým číslem scénáře roste i jejich přesvědčení o jeho kvalitě.

Hasar, E. (2019). A Comparison between European Digital Competence Framework and the Turkish ICT Curriculum. Online Submission, 7(4), 954-962.

Studie nabízí pečlivé srovnání mezi DigComp (jehož domény jsou zde vnímané cyklicky od 1 do 5 jako na sebe navazující a neustále se opakující) a novým tureckým kurikulem výuky ICT. Ukazuje se, že některá témata (netiketa, občanská participace, ale částečně i řešení problémů) v tureckém kurikulu chybí. Článek nenabízí jasnou odpověd', proč tomu tak je, ale naznačuje dvojí - jde jak o kulturní problém (participace není žádaná), tak o otázku nějaké „obsahové měkkosti“", které mohou vést k tomu, že část kurikula není brána tak vážně jako ta, která je snáze a exaktněji měřitelná.

Zeehan, F., Alias, R. A., \& Z, T. (2020). Mapping the attribute of digital competency framework for educators. International Journal Of Psychosocial Rehabilitation, 24(6), 2361-2371. https://doi.org/10.37200/IJPR/V24I6/PR260225

Studie se zaměřuje, na základě výzkumu, na skutečnost, že technologické změny tedy i rozvoj digitálních kompetencí - musí nutně znamenat transformaci didaktických 
metod. Pracuje s velice zajímavou metodologií mapování, která může být použita nejen pro empirický výzkum, ale i pro autoevaluaci a rozvoj kompetencí učitelů.

\section{Analýza}

Studie, které jsme představili výše, nabízejí poměrně komplexní pohled na digitální kompetence, jako na společensky významný problém. Krumsvik (2008) dokonce hovoří o epistemické slepotě - bez digitálních kompetencí není možné být v současné, komplexní a do značné míry digitalizované společnosti vidoucí. Tato epistemická slepota přitom může vést k několika značně odlišným prístupům - od představy, že je třeba ji rychle a efektivně odstranit, až po názor, že tím, že je něčím dočasným, není třeba se jí skutečně významně zabývat. Domníváme se, že myšlenková východiska Krumsvika $(2008,2014)$ jsou ale stále platná a mají potenciálně velké dopady. A to jak na praktický pedagogický výkon, tak také možnosti samotných žáků se vzdělávat.

Není možné dlouhodobě podporovat edukační systém, který k této epistemické slepotě vede, nebo který ji dokonce systémově podporuje. V mnoha studií je možné vidět, že výzkumníci se opírají o přesvědčení, že změna je možná jen skrze rychlou a významnou reformu - at' již jde o norskou cestu (Krumsvik 2014) nebo Španělský model (PérezEscoda 2014, Napal Fraile et al. 2018). Prvním krokem pro odstranění této slepoty je tedy vzdělávání učitelů.

Nejde přitom jen o učení založené na schopnosti ovládat techniku, ale v podstatě všechny studie akcentují i téma hlubší didaktické i obsahové proměny vzdělávání. To, že učitel zvládne využívat určitý nástroj totiž neznamená automaticky jeho schopnost implementace do vzdělávání nebo oborového rámce. Je třeba hledat nástroje, které učitelům takovou implementaci umožní. S ohledem na studii Zeehana (2020) lze také říci, že tato proměna bude zahrnovat do značné míry i didaktická očekávání, tedy komplexní proměnu toho, jak vzdělávání má vypadat.

Technika tak není něčím vnějším, co je možné bez větších změn promítat do učebního procesu, ale instrument natolik široké transformativní změny, že je možné o něm uvažovat jako o jednom z možných aktérů celého edukačního procesu. Digitální kompetence tedy budou otevírat nové možnosti a směry vzdělávání, což je možná aspekt, který většina studií - byt' na to upozorňuje např́klad Köhler (2019) - zatím neumí zcela docenit.

Při analýze vlastních východisek textů je možné sledovat jednak jistý intuitivní pramen spočívající v přesvědčení, že digitální kompetence (at' je jimi míněno cokoliv) jsou pro život v moderní společnosti nezbytné. Na tomto intuitivně zřejmém základu jsou pak stavěna další úvahy zaměřené především na vzdělávání, at' již klasické školní nebo třeba na přípravu pedagogů. Druhým významným zdrojem je rámec DigComp (respektive DigCompEdu), opírající se o evropské strategické dokumenty. Nacházíme ho často ve výzkumných studiích, ale současně také že slouží jako jistý referenční rámec (Hasar 2019, Lucas 2017), určující, jak by mělo takové vzdělávání v digitálních kompetencích vypadat. U učitelsky orientované literatury je pak silný vliv především Krumsvika (2008), který tvoří základní autoritu v celém tématu.

Poměr empirických a teoretických studií je v naší analýze v podstatě vyrovnaný. To, co ale jistě stojí za zmínku, je pohled do použitých výzkumných metod. Setkáváme se spíše s menšími výzkumnými sondami, které akcentují práci se sebehodnocením (Napal Fraile et al. 2018, Yazon et al. 2019). Právě subjektivně orientované metody jsou značně převažující. To na jedné straně souvisí s tím, jak jsou konstruovány kompetenční rámce 
(DigComp i DigCompEdu), provést takovou evaluaci může být validní i reliabilní, ale současně jde o prrístup zatížený poměrně velkou systematickou chybou v podobě předpokladu kompetence $\mathrm{k}$ sebehodnocení, která nemusí být vždy silná. S výjimkou náročného výzkumu Janssena (2013) jsou v podstatě všechny empirické studie poměrně snadno replikovatelné.

Patrná je také skutečnost, že autorský sentiment je silně negativní - digitální kompetence nejsou dostatečně rozvinuté, existuje hluboký př́kop mezi očekáváním pracovního trhu a tím, co dokáže kurikulárně zajistit škola atp. Ten je narušován bud' prezentací vlastních úspěchů (Krumsvik 2012), které ovšem na jistém negativním či skeptickém základu stojí také, nebo širšími teoretickými úvahami (Janssen et al. 2013, Köhler 2019). Tato skepse vychází přitom nikoli z nějakého subjektivního přesvědčení, ale $\mathrm{z}$ dat, se kterými výzkumníci pracují. Zdá se být nad veškeré pochybnosti zrejejmé, že autoři vzdělávacích politik a kurikul musí $\mathrm{v}$ této oblasti prokázat mimořádnou aktivitu a výzkumnou i aplikační pozornost.

Je možné nalézt shodu na tom, co je to digitální kompetence? Takový koncensus by mohl představovat základní bod pro výše naznačený požadavek aktivní práce s tématem. Janssen (2013) je v této oblasti velice kritický a říká, že takovou shodu zřejmě nalézt nemůžeme. Upozorňuje na skutečnost, s níž souhlasíme a potvrzují nám ji další výzkumy (Černý 2020, Černý 2020b), že digitální kompetence není izolovaným projevem něčeho čistě digitálního. Její součástí jsou i kompetence $\mathrm{k}$ učení se, schopnost komunikovat skrze technologie nebo jejich užití v určitém etickém a legislativním rámci. To, co bychom rádi zdůraznili je aspekt každodennosti. Tak, jako v historiografii můžeme ve 20. století vidět obrat ke každodennosti jako ke klíči k pochopení života a myšlení lidí, tedy dějin jako takových (Kudrna 1980, Sedlák 2013, Le Goff 1992), tak digitální kompetence sledují podobný cíl, silně kotvený v každodennosti. Digitální kompetence je něčím, co člověku pomáhá zvládat úkoly všedního dne a co je současně jeho základní epistemickou výbavou.

Zdá se, že strategie spočívající v převzetí DigComp jako základního referenčního rámce pro vzdělávání $\mathrm{v}$ digitálních kompetencích $\mathrm{s}$ ohledem na občanskou společnost, je něčím, na čem panuje širší výzkumný koncensus. Jde o kompetence, které je možné označit jako základní nebo jádrové, a $\mathrm{k}$ nim je třeba přidávat další vrstvy v závislosti na konkrétních profesních potřebách a požadavcích.

Köhler (2019) upozorňuje, že „dějiny nejsou uzavřené“ není možné ř́ci, že vývoj vzdělávání půjde jedním nebo druhým směrem. Každé specifické uchopení preferovaných hodnot a cílů bude v budoucnosti akcentovat jinou potřebnou kompetenční sadu. A to jak $\mathrm{u}$ učitelů, tak u celé společnosti. Toto vidění světa $\mathrm{v}$ jisté otevřenosti je nesmírně důležité. Jakkoli to může znít pateticky, domníváme se, že např́ílad u českého školského systému není tím klíčovým aktérem tvůrce kurikulární politiky na úrovni státu, ale ředitel školy (Šíp 2019) - ten rozhoduje o scénáři, se kterým bude škola pracovat. Jeho možnosti jsou $\mathrm{v}$ tomto směru mimořádně široké, stejně jako $\mathrm{v}$ př́padě děkanů fakult nebo rektorů vysokých škol.

\section{Diskuse}

Rádi bychom na tomto místě částečně poodstoupili od jednotlivých témat analyzovaných textů a dotkly se několika otázek či problémů, které předložené studie předestírají. 
Předně je třeba vyjasnit, v čem spočívá ona epistemická slepota a jak přesně souvisí

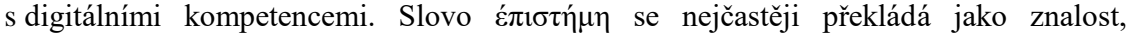
$\mathrm{v}$ angličtině se setkáme i s překladem věda (science). Věda ani znalost není něčím, co lze snadno přenést mezi dvěma aktéry komunikace. Aby se z nějakého zdání nebo vidění, mohla stát znalost, je třeba, aby došlo k její vnitřní transformaci. Prokop (2019) pracuje s pojmem slepá skvrna ve smyslu sociálně sdíleného předsudku, jako struktury, která nám znemožňuje vidět svět správně. Ona epistemická slepota má tedy několik, vzájemně propojených rovin: a) znemožňuje člověku správně chápat svět, tomu, co se v něm děje; b) znemožňuje vidět a vnímat jistou třídu jevů; c) znemožňuje člověku aktivní činnost ve světě.

Všechny tři dimenze jsou přitom s konceptem kompetence silně propojené. Kompetence umožňuje jak vidění a chápání jistého okrsku problémů, tak možnost s nimi aktivně pracovat. Epistemologie není jen pasivním zřením na svět, ale musí být spojená $\mathrm{s}$ poznávající aktivitou, která je kotvená v prostředí. Ono ponoření se v Umwelt, ve kterém dochází ke konstituci poznání, jak zdůrazňují Berger a Luckmann (2001), není pasivní činností, ale aktivním bytím v určité situaci. A k tomuto bytí, které je stále více onlife (Floridi 2015), tedy nerozlučitelně propojené online a off-line, se digitální kompetence silně vztahují. Epistemická slepota tedy není nějakým partikulárním či okrajovým tématem, ale představuje problém zcela zásadního charakteru. V tradiční scholastické struktuře je totiž smyslem školy učinit z nevidoucích vidoucí, provést jejich změnu, která je tak hluboká, že transformuje celé jejich vnitřní uspořádání.

Současně se zdá stále zřetelnější, že i když nemáme zcela jasno v tom, co to digitální kompetence vlastně jsou, tak to, jak silně jsou spojené s prostředím, dává tušit, že jejich zavedení jako určité subjektivní kognitivní mohutnosti jedince, je neudržitelné. Je nutné pracovat s konceptem kompetence jako vztahové procesuální temporálně závislé struktury enviromentální povahy. Toto pojetí se pak musí odrazit také ve způsobu jejího (či jejich) rozvíjení, testování a kurikulárního vnímání. Takovýto pohled současně umožní vysvětlit, proč o digitálních kompetencích není možné uvažovat čistě digitálně nebo technologicky, (Janssen et al. 2013) ale proč je třeba je propojovat s dalšími aspekty či druhy kompetencí.

Toto pojetí nám umožňuje pokusit se nějak blíže se dotknout problému tvorby modelů kompetenčních rámců tak, jak jsou v naší analýze naznačené. Jak DigComp tak také DigCompEdu pracují s jistým předpokladem společenské role. Občan i učitel (český překlad neuvádí přesnější vzdělavatel, ale učitel, proto se ho i zde přidržíme) jsou role, které je možné spojit s osobou v určitém prostředí, která se v tomto prostředí určitým způsobem uskutečňuje. Domníváme se, že jde pravděpodobně o jediný možný prakticky orientovaný přistup, který má zřejmé kořeny v pragmatismu (učení se založené na situaci) a fenomenologii (proces postupného stávání se, jako výsledek procesu učení).

První př́iklad, který je možné zvolit, je kurikulární reforma výuky informatiky v Turecku (Hasar 2019) - ta je soustředěná skutečně primárně na informatiku, nikoli na digitální kompetence jako takové. Skutečnost, že se vůbec nevěnuje např́íklad občanské participaci nebo netiketě, by měla vyvolat otázku, co je cílem takového kompetenčního modelu, na kterém kurikulum stojí. Je to výchova občana schopného budovat aktivní společenské vazby? Zdá se, že mnohem blíže má k herbartovskému modelu vzdělávání stojícího na požadavcích praxe. Může tedy posloužit jako nástroj pracovního uplatnění, ale nikoliv jako občansky formující nástroj. 
Pokud naopak srovnáme ECDL a DigComp, nacházíme vlastně zcela totožnou rozvahu. Pro první model je cílem dosažení rovnováhy a úspěchu v kancelářské administrativní práci, pro druhý je patrný akcent na spolubytí (Mitsein) a aktivní občanství. Jak jeden, tak druhý přístup může být v určitém ohledu efektivní a výhodný. Domníváme se však, že smyslem vzdělání, alespoň ve školním prostředí, by měl být druhý z nich. Cílem je aktualizace a rozvoj bytí ve společnosti, vybavení epistemickými nástroji pro život v ní, nikoli instrumentální zvládání konkrétních úkonů, které může být sice praktické a užitečné, ale netvoří dostatečný osobnostní základ.

Takzvaný španělský model pracuje s kompetencemi v pěti dimenzích: technické, informační a komunikační, vzdělávací, sebereflexivní a sociální a etické. Klíčové je, že vidí učitele jako člověka $\mathrm{v}$ určitém prostředí, $\mathrm{v}$ němž se musí umět chovat. Je zajímavý v tom, že se snaží zasáhnout jak dovednosti instrumentální a technické, tak také systematicky pracovat $\mathrm{s}$ osobností daného jedince a vést ho $\mathrm{k}$ tomu, že technologie skutečně proměňují i další aspekty jejich práce a života. To, že dokáže digitální kompetence explicitně propojit s etikou, sociální sférou nebo sebereflexí znamená, že model je jednoznačně ekologicky zaměřený. Žádný jedinec v něm nemá kompetence jako izolovaný bod, ale kompetence jsou konstituovány skrze propozice (Buber 2003) $\mathrm{k}$ prostředí.

Norský model vnímá prostředí jako východisko, jako faktum, do nějž vstupuje učitel, který má poměrně jasný atomický charakter. Je to ale prostředí (i on sám), které postupně strukturuje to, co si z kompetencí musí nebo nemusí odnášet. Je pozváním nikoli $\mathrm{k}$ hotovosti, ale $\mathrm{k}$ určitému postupnému aditivnímu doplňování toho, co člověku chybí $\mathrm{k}$ tomu, aby byl dobrým digitálně kompetentním učitelem. Právě aditivnost je slabinou tohoto modelu, který př́liš nebere v potaz ani transformace strukturní (nové technologie a kompetence mění svět i porozumění mu), ani temporální aspekt (kompetence musí být neustále aktualizovaná a rozvíjená, jinak vyhasíná).

\section{Závěr}

Z námi analyzovaných textů se zřejmě nejvíce odpovědi na otázku, jak definovat a vymezit pojem digitálních kompetencí blížil Janssen (2013). I tento text ale jasně odkrývá, že snadné přiklonění se na stranu digitálních kompetencí místo digitální gramotnosti nebo $\mathrm{k}$ jedné či více kompetencím, není snadný úkol a že literatura na toto téma je silně nesourodá. Současně ale jasně odkrývá skutečnost, že digitální kompetence nemůže být izolovaným fenoménem.

Souhlasíme také s poměrně silným většinovým názorem (v námi analyzovaných textech), že je nutné rozvoj digitálních kompetencí na úrovni pregraduální př́ípravy učitelů významně posílit, ale současně že nejde jen o ni - není možné tímto způsobem „opustit“ ostatní učitele, kteří se již ve fakultním prostředí nenacházejí. V tomto ohledu je norský př́stup (Krumsvik 2008) velkou a důležitou inspirací v tom, jak pracovat s jednotlivými učiteli.

Současně ale platí, jak naznačuje Köhler (2019), že stojíme na rozcestí. Před volbou, jaké vzdělávání chceme mít a současně jaký kompetenční profil s ním chceme spojovat. Jak upozorňuje Burns (2020) technologie by neměly být něčím, co se stane samo o sobě modlou nebo jediným a hlavním cílem vzdělávání. Musíme být připraveni snít o tom, jaké vzdělávání má být. A na základě tohoto snu hledat cesty k jeho realizaci. 


\section{Literatura}

Berger, P. L., \& Luckmann, T. (2001). Sociálni konstrukce reality: pojednání o sociologii vědění. CDK.

Borgman, C. L., \& Larsen, R. (2003). ECDL 2003 Workshop report: Digital library

evaluation-metrics, testbeds and processes. D-lib magazine, 9(9), 1082-9873.

Buber, M. (2005). Já a Ty. Praha: Kalich.

Burns, R. (2020). A COVID-19 panacea in digital technologies? Challenges for democracy and higher education. Dialogues in Human Geography, 2043820620930832. Calzarossa, M. C., Ciancarini, P., Maresca, P., Mich, L., \& Scarabottolo, N. (2007). The ECDL programme in Italian universities. Computers \& Education, 49(2), 514-529.

Carretero, S., Vuorikari, R., \& Punie, Y. (2017). DigComp 2.1: The Digital Competence Framework for Citizens with eight proficiency levels and examples of use (No.

JRC106281). Joint Research Centre (Seville site).

Černý, M. (2020). Kdo je digitálně kompetentní člověk? Empirická studie výroků studentů (převážně) Filozofické fakulty Masarykovy univerzity. Journal of Technology and Information Education. 1(12), s. 44-60.

Černý, M. (2020b). Reflexe evropského rámce digitálních kompetencí studenty (především) Filozofické fakulty MU optikou kvalitativního výzkumu. Gramotnost, pregramotnost a vzdělávání. 1(4)

Dombrovská, M. (2001). Informační gramotnost: funkční gramotnost v informační společnosti. Diplomová práce. Praha: Ústav informačních studii UK.

Dombrovská, M., Landová, H., \& Tichá, L. (2004). Informační gramotnost-teorie a praxe v ČR. Národní knihovna, 15(1), s. 7-18.

Evangelinos, G., \& Holley, D. (2014, September). A qualitative exploration of the EU digital competence (DIGCOMP) framework: a case study within healthcare education. In International Conference on E-Learning, E-Education, and Online Training (pp. 8592). Springer, Cham.

Floridi, L. eds (2015) The Onlife Manifesto: Being Human in a Hyperconnected Era. Springer International Publishing.

Hasar, E. (2019). A Comparison between European Digital Competence Framework and the Turkish ICT Curriculum. Online Submission, 7(4), 954-962.

Janssen, J., Stoyanov, S., Ferrari, A., Punie, Y., Pannekeet, K., \& Sloep, P. (2013). Experts' views on digital competence: Commonalities and differences. Computers \& Education, 68, 473-481.

Johnson, N., Veletsianos, G., Seaman, J. (2020) U.S. Faculty and Administrators' Experiences and Approaches in the Early Weeks of the COVID-19 Pandemic. OLJ. 10.24059/olj.v24i2.2285.

Köhler, T., Wollersheim, H. W., \& Igel, C. (2019, July). Scenarios of Technology Enhanced Learning (TEL) and Technology Enhanced Teaching (TET) in Academic Education A Forecast for the Next Decade and its Consequences for Teaching Staff. In 2019 8th International Congress on Advanced Applied Informatics (IIAI-AAI) (pp. 240-245). IEEE.

Krumsvik, R. J. (2008). Situated learning and teachers' digital competence. Education and Information Technologies, 13(4), 279-290.

Krumsvik, R. J. (2014). Teacher educators' digital competence. Scandinavian Journal of Educational Research, 58(3), 269-280. 
Kudrna, J. (1980). K některým aspektům geneze metod školy Annales.

Le Goff, J. (1992). History and memory. Columbia University Press.

Leigh, J., Vasilica, C., Dron, R., Gawthorpe, D., Burns, E., Kennedy, S., ... Croughan, C. (2020). Redefining undergraduate nurse teaching during the coronavirus pandemic: use of digital technologies. British Journal of Nursing, 29(10), 566-

569. doi:10.12968/bjon.2020.29.10.566

Longhurst, G. J., Stone, D. M., Dulohery, K., Scully, D., Campbell, T., \& Smith, C. F. (2020). Strength, Weakness, Opportunity, Threat (SWOT) Analysis of the Adaptations to Anatomical Education in the United Kingdom and Republic of Ireland in Response to the Covid-19 Pandemic. Anatomical sciences education, 13(3), 301-311.

Lucas, M., Moreira, A., \& Costa, N. (2017). Quadro europeu de referência para a competência digital: subsídios para a sua compreensão e desenvolvimento. Observatorio $\left(\mathrm{Obs}^{*}\right), 11(4)$.

Napal Fraile, M., Peñalva-Vélez, A., \& Mendióroz Lacambra, A. M. (2018).

Development of digital competence in secondary education teachers' training. Education Sciences, 8(3), 104.

Pavelková, J., Knaifl, O., \& Preuss, K. (2012). Funkční a finanční gramotnost. Speciální pedagogika. (22)2, s. 108-119.

Pérez-Escoda, A. (2014, October). Digital competence's frameworks in Europe: an approaching to Spanish and Norwegian framework. In Proceedings of the Second International Conference on Technological Ecosystems for Enhancing Multiculturality (pp. 469-474).

Prendes Espinosa, M. P., Gutierrez Porlan, I., \& Martinez Sanchez, F. (2018). Digital competence: a need for university teachers in the 21 st century. RED-REVISTA DE EDUCACION A DISTANCIA, (56).

Prokop, D. (2019) Slepé skvrny. Brno: Host.

Roushan, G., Holley, D., \& Biggins, D. (2016). The kaleidoscope of voices: An action research approach to informing institutional e-learning policy. Electronic Journal of ELearning, 14(5), 293-300.

Sedlák, P. (2013). Každodennost jako předmět a koncept dějepisného poznání. Soudobé dějiny, 20(01-02), 120-157.

Siddoo, V., Sawattawee, J., Janchai, W., \& Yodmongkol, P. (2017). Exploring the competency gap of it students in Thailand: The employers' view of an effective workforce. Journal of Technical Education and Training, 9(2).

Š́p, R. (2019). Proč školy selhávaji: kognitivni krajiny a nacionalismus. Brno: Masarykova univerzita.

Špernjak, A., \& Šorgo, A. (2018, May). Outlines for science digital competence of elementary school students. In 201841 st International Convention on Information and Communication Technology, Electronics and Microelectronics (MIPRO) (pp. 08250829). IEEE.

Teodorescu, T. (2006). Competence versus competency: What is the difference?

Performance Improvement, 45(10), 27-30.

Veteška, J., Tureckiová, M. (2008) Kompetence ve vzdělávání. Praha: Grada.

Yazon, A., Ang-Manaig, K., Buama, C. A. C., \& Tesoro, J. F. B. (2019). Digital literacy, digital competence and research productivity of educators. Universal Journal of Educational Research, 7(8), 1734-1743. 
Zeehan, F., Alias, R. A., \& Z, T. (2020). Mapping the attribute of digital competency framework for educators. International Journal Of Psychosocial Rehabilitation, 24(6), 2361-2371. https://doi.org/10.37200/IJPR/V24I6/PR260225 


\begin{tabular}{|c|c|c|c|c|c|c|c|c|c|c|}
\hline Název studie & Stát & $\begin{array}{l}\text { Druh } \\
\text { studie: } \\
\text { Empiri } \\
\text { cká / } \\
\text { teoretic } \\
\text { ká }\end{array}$ & $\begin{array}{l}\text { Výzkum } \\
\text { ný } \\
\text { vzorek }\end{array}$ & Klíčová zjištění & $\begin{array}{l}\text { Výzkum } \\
\text { né } \\
\text { nástroje } \\
\text { (u } \\
\text { empirick } \\
\text { é studie) }\end{array}$ & $\begin{array}{l}\text { Rok } \\
\text { vydání }\end{array}$ & Jazyk & $\begin{array}{l}\text { Počet } \\
\text { citačníc } \\
\text { h } \\
\text { ohlasů } \\
\text { Google } \\
\text { Scholar }\end{array}$ & $\begin{array}{l}\text { Počet } \\
\text { citačníc } \\
\text { h } \\
\text { ohlasů } \\
\text { WoS }\end{array}$ & 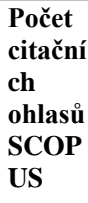 \\
\hline $\begin{array}{l}\text { Teacher } \\
\text { educators' } \\
\text { digital } \\
\text { competence }\end{array}$ & Norsko & $\begin{array}{l}\text { Teoreti } \\
\text { cká }\end{array}$ & & $\begin{array}{l}\text { Digitální kompetence se } \\
\text { staly jedním z pilířu } \\
\text { vzdělávání učitelů, hovoří } \\
\text { se o digitálním "bildung" a } \\
\text { celé vzdělávání a má } \\
\text { graduální charakter. Důraz } \\
\text { je kladen na kombinaci } \\
\text { teoretické a praktické } \\
\text { složky vzdělávání, které se } \\
\text { musí rozvíjet společně. }\end{array}$ & & 2014 & angličtina & 191 & 62 & 59 \\
\hline $\begin{array}{l}\text { Experts' } \\
\text { views on } \\
\text { digital } \\
\text { competence: } \\
\text { Commonalit } \\
\text { ies and } \\
\text { differences }\end{array}$ & $\begin{array}{l}\text { Nizozem } \\
\text { sko }\end{array}$ & $\begin{array}{l}\text { Empiric } \\
\text { ká }\end{array}$ & $\begin{array}{l}95 \\
\text { odborník } \\
\text { ů z } \\
\text { Evropy i } \\
\text { mimo ni }\end{array}$ & $\begin{array}{l}\text { Na tom, co jsou to digitální } \\
\text { kompetence nepanuje } \\
\text { paradigmatická shoda. } \\
\text { Současně je žrejmé, že } \\
\text { není možné je identifikovat } \\
\text { s prostým uživáním } \\
\text { techniky, byt' by bylo } \\
\text { časté. Mohou být vztaženy } \\
\text { na kognitivní nebo } \\
\text { znalostní úroveň. }\end{array}$ & $\begin{array}{l}\text { Delfská } \\
\text { metoda }\end{array}$ & 2013 & angličtina & 165 & 61 & 52 \\
\hline
\end{tabular}




\begin{tabular}{|c|c|c|c|c|c|c|c|c|c|c|}
\hline $\begin{array}{l}\text { Situated } \\
\text { learning and } \\
\text { teachers' } \\
\text { digital } \\
\text { competence }\end{array}$ & Norsko & $\begin{array}{l}\text { Teoreti } \\
\text { cká }\end{array}$ & & $\begin{array}{l}\text { Model se zaměřuje na čtyři } \\
\text { základní složky: základní } \\
\text { dovednosti v oblasti ICT, } \\
\text { didaktické dovednosti v } \\
\text { oblasti ICT, strategie učení } \\
\text { a "digital bildung". } \\
\text { Poslední položka se pak } \\
\text { vztahuje k bytí v digitální } \\
\text { společnosti, digitalizované } \\
\text { škole či jiné komunitě. }\end{array}$ & & 2008 & angličtina & 208 & 39 & 47 \\
\hline $\begin{array}{l}\text { Developmen } \\
\text { t of digital } \\
\text { competence } \\
\text { in secondary } \\
\text { education } \\
\text { teachers' } \\
\text { training }\end{array}$ & $\begin{array}{l}\text { Španělsk } \\
\text { o }\end{array}$ & $\begin{array}{l}\text { Empiric } \\
\text { ká }\end{array}$ & $\begin{array}{l}43 \\
\text { studentů } \\
\text { učitelství }\end{array}$ & $\begin{array}{l}\text { Studenti učitelství se } \\
\text { v digitálních kompetencích } \\
\text { hodnotí velice slabě. Škola } \\
\text { jim nedává dostatečné } \\
\text { nástroje pro formální } \\
\text { edukaci v této oblasti. }\end{array}$ & $\begin{array}{l}\text { Sebehodn } \\
\text { ocení dle } \\
\text { DigComp }\end{array}$ & 2018 & angličtina & 34 & 10 & 13 \\
\hline $\begin{array}{l}\text { A qualitative } \\
\text { exploration } \\
\text { of the EU } \\
\text { digital } \\
\text { competence } \\
\text { (DIGCOMP } \\
\text { ) } \\
\text { framework: } \\
\text { A case study } \\
\text { within } \\
\text { healthcare } \\
\text { education }\end{array}$ & $\begin{array}{l}\text { Velká } \\
\text { Británie }\end{array}$ & $\begin{array}{l}\text { Empiric } \\
\text { ká }\end{array}$ & $\begin{array}{l}5 \\
\text { akademi } \\
\text { ků, } 3 \\
\text { studenti, } \\
3 \\
\text { administ } \\
\text { rativní } \\
\text { pracovní } \\
\text { ci }\end{array}$ & $\begin{array}{l}\text { Respondenti se silně } \\
\text { opírají o kompetence } \\
\text { zaměřené na učení se, } \\
\text { zábavu a přijem informací. } \\
\text { Naopak se ukazuje, že } \\
\text { sociální aspekty využitích } \\
\text { technologií a jejich širší } \\
\text { uchopení nebylo pro } \\
\text { zdravotníky tak významné. }\end{array}$ & $\begin{array}{l}\text { Rozhovor } \\
\text { y }\end{array}$ & 2014 & angličtina & 14 & 0 & 7 \\
\hline
\end{tabular}




\begin{tabular}{|c|c|c|c|c|c|c|c|c|c|c|}
\hline $\begin{array}{l}\text { Digital } \\
\text { competence: } \\
\text { A need for } \\
\text { university } \\
\text { teachers in } \\
\text { the } 21 \text { st } \\
\text { century }\end{array}$ & $\begin{array}{l}\text { Španělsk } \\
\text { o }\end{array}$ & $\begin{array}{l}\text { Empiric } \\
\text { ko- } \\
\text { teoretic } \\
\text { ká }\end{array}$ & & $\begin{array}{l}\text { Článek navrhuje vlastní } \\
\text { model př́ipravy učitelů, } \\
\text { který v jistém ohledu } \\
\text { kombinuje pohledy } \\
\text { DigCompEdu a } \\
\text { Krumsvika. }\end{array}$ & $\begin{array}{l}\text { Analýza } \\
\text { současné } \\
\text { ho stavu } \\
\text { škol }\end{array}$ & 2018 & španělština & 0 & 6 & 6 \\
\hline $\begin{array}{l}\text { Exploring } \\
\text { the } \\
\text { competency } \\
\text { gap of it } \\
\text { students in } \\
\text { Thailand: } \\
\text { The } \\
\text { employers' } \\
\text { view of an } \\
\text { effective } \\
\text { workforce }\end{array}$ & Thajsko & $\begin{array}{l}\text { Empiric } \\
\text { ká }\end{array}$ & $\begin{array}{l}49 \\
\text { organiza } \\
\text { cí }\end{array}$ & $\begin{array}{l}\text { Existují velké rozdíly mezi } \\
\text { očekáváním } \\
\text { zaměstnavatelů a tím, co } \\
\text { jsou schopny v kurikulu } \\
\text { zachytit univerzity ve } \\
\text { velké části digitálních } \\
\text { kompetencí. Text zajímavě } \\
\text { ukazuje, že existuje něco } \\
\text { jako neporozumění mezi } \\
\text { univerzitou a trhem v tom, } \\
\text { co je to profil absolventa, } \\
\text { respektive, jak vypadá } \\
\text { člověk připravený do } \\
\text { praxe. }\end{array}$ & $\begin{array}{l}\text { Dotazník } \\
\text { a } \\
\text { statistick } \\
\text { á analýza }\end{array}$ & 2017 & angličtina & 5 & 1 & 3 \\
\hline $\begin{array}{l}\text { Outlines for } \\
\text { science } \\
\text { digital } \\
\text { competence } \\
\text { of } \\
\text { elementary } \\
\text { school } \\
\text { students }\end{array}$ & $\begin{array}{l}\text { Slovinsk } \\
\text { o }\end{array}$ & $\begin{array}{l}\text { Teoreti } \\
\text { cká }\end{array}$ & & $\begin{array}{l}\text { Text popisuje tři roviny } \\
\text { digitální kompetence - } \\
\text { obecnou, obecnou } \\
\text { učitelskou a speciální } \\
\text { vědeckou zaměřenou na } \\
\text { konkrétní vědu. Každá ze } \\
\text { tří roviny je něčím odlišná. } \\
\text { Aby bylo dosaženo jejich } \\
\text { dostatečné kvality, } \\
\text { navrhují autoři studie } \\
\text { provádět externí certifikaci } \\
\text { učitelů. }\end{array}$ & & 2018 & angličtina & 2 & 0 & 2 \\
\hline
\end{tabular}




\begin{tabular}{|c|c|c|c|c|c|c|c|c|c|c|}
\hline $\begin{array}{l}\text { The } \\
\text { European } \\
\text { digital } \\
\text { competence } \\
\text { framework: } \\
\text { Contributio } \\
\text { n for its } \\
\text { comprehensi } \\
\text { on and } \\
\text { development }\end{array}$ & $\begin{array}{l}\text { Portugals } \\
\text { ko }\end{array}$ & $\begin{array}{l}\text { Teoreti } \\
\text { cká }\end{array}$ & & $\begin{array}{l}\text { Text se věnuje } \\
\text { myšlenkovým } \\
\text { východiskům Digcomp a } \\
\text { jeho možné praktické } \\
\text { implementaci v } \\
\text { Portugalském prostředí. }\end{array}$ & & 2017 & $\begin{array}{l}\text { portugalštin } \\
\text { a }\end{array}$ & 6 & 0 & 2 \\
\hline $\begin{array}{l}\text { The } \\
\text { kaleidoscope } \\
\text { of voices: An } \\
\text { action } \\
\text { research } \\
\text { approach to } \\
\text { informing } \\
\text { institutional } \\
\text { e-learning } \\
\text { policy }\end{array}$ & $\begin{array}{l}\text { Velká } \\
\text { Británie }\end{array}$ & $\begin{array}{l}\text { Empiric } \\
\text { ká }\end{array}$ & $\begin{array}{l}1 \\
\text { universit } \\
\mathrm{a}\end{array}$ & $\begin{array}{l}\text { Klíčové pro inovace ve } \\
\text { vzdělávání je jednak } \\
\text { rozvíjet kompetence } \\
\text { aktivně pracující s } \\
\text { digitálními nástroji, ale } \\
\text { také chápat dobře potřeby } \\
\text { většiny v dané instituci. }\end{array}$ & $\begin{array}{l}\text { Akční } \\
\text { výzkum }\end{array}$ & 2016 & angličtina & 7 & 5 & 2 \\
\hline $\begin{array}{l}\text { Digital } \\
\text { competence' } \\
\text { s } \\
\text { frameworks } \\
\text { in Europe: } \\
\text { An } \\
\text { approaching } \\
\text { to Spanish } \\
\text { and } \\
\text { Norwegian } \\
\text { framework }\end{array}$ & $\begin{array}{l}\text { Španělsk } \\
\text { o }\end{array}$ & $\begin{array}{l}\text { Teoreti } \\
\text { cká }\end{array}$ & & $\begin{array}{l}\text { Komparace DigComp, } \\
\text { Španělského a } \\
\text { Krumsvikova modelu } \\
\text { digitálních kompetencí. }\end{array}$ & & 2014 & angličtina & 3 & 0 & 2 \\
\hline
\end{tabular}




\begin{tabular}{|c|c|c|c|c|c|c|c|c|c|c|}
\hline $\begin{array}{l}\text { Digital } \\
\text { literacy, } \\
\text { digital } \\
\text { competence } \\
\text { and research } \\
\text { productivity } \\
\text { of educators }\end{array}$ & Filipíny & $\begin{array}{l}\text { Empiric } \\
\text { ká }\end{array}$ & $\begin{array}{l}\text { Akademi } \\
\text { ci - blíže } \\
\text { nezjištěn } \\
\text { ý počet }\end{array}$ & & $\begin{array}{l}\text { Statistick } \\
\text { é metody }\end{array}$ & 2019 & angličtina & 6 & 0 & 1 \\
\hline $\begin{array}{l}\text { Scenarios of } \\
\text { Technology } \\
\text { Enhanced } \\
\text { Learning } \\
\text { (TEL) and } \\
\text { Technology } \\
\text { Enhanced } \\
\text { Teaching } \\
\text { (TET) in } \\
\text { Academic } \\
\text { Education A } \\
\text { Forecast for } \\
\text { the Next } \\
\text { Decade and } \\
\text { its } \\
\text { Consequenc } \\
\text { es for } \\
\text { Teaching } \\
\text { Staff. }\end{array}$ & Německo & $\begin{array}{l}\text { Teoreti } \\
\text { cká }\end{array}$ & & $\begin{array}{l}\text { Porovnání čtyř možných } \\
\text { scénářů vývoje vzdělávání } \\
\text { a jeho dopady na učitelské } \\
\text { kompetence. Pracuje s } \\
\text { DigCompEdu }\end{array}$ & & 2019 & angličtina & 2 & 0 & 1 \\
\hline $\begin{array}{l}\text { A } \\
\text { comparison } \\
\text { between } \\
\text { european } \\
\text { digital } \\
\text { competence } \\
\text { framework }\end{array}$ & Turecko & $\begin{array}{l}\text { Empiric } \\
\text { ko- } \\
\text { teoretic } \\
\text { ká }\end{array}$ & $\begin{array}{l}\text { Turecké } \\
\text { kurikulu } \\
\text { m a } \\
\text { kompete } \\
\text { nční } \\
\text { rámec }\end{array}$ & $\begin{array}{l}\text { V tureckém kurikulu (proti } \\
\text { DigComp) chybí témata } \\
\text { občanské participace, } \\
\text { netikety, ale částečně i } \\
\text { řešení problémů. }\end{array}$ & $\begin{array}{l}\text { Analýza } \\
\text { kurikula }\end{array}$ & 2019 & angličtina & 1 & 0 & 1 \\
\hline
\end{tabular}




\begin{tabular}{|c|c|c|c|c|c|c|c|c|c|c|}
\hline $\begin{array}{l}\text { and the } \\
\text { Turkish ICT } \\
\text { curriculum }\end{array}$ & & & & & & & & & & \\
\hline $\begin{array}{l}\text { Mapping the } \\
\text { attribute of } \\
\text { digital } \\
\text { competency } \\
\text { framework } \\
\text { for } \\
\text { educators }\end{array}$ & Malajsie & $\begin{array}{l}\text { Empiric } \\
\text { ká }\end{array}$ & & $\begin{array}{l}\text { Změna digitálních } \\
\text { kompetencí implikuje } \\
\text { změnu očekávaných } \\
\text { didaktických forem. }\end{array}$ & $\begin{array}{l}\text { Mapován } \\
\text { í }\end{array}$ & 2020 & angličtina & 0 & 0 & 0 \\
\hline Název studie & Stát & $\begin{array}{l}\text { Druh } \\
\text { studie: } \\
\text { Empiric } \\
\text { ká / } \\
\text { teoretic } \\
\text { ká }\end{array}$ & $\begin{array}{l}\text { Výzkum } \\
\text { ný } \\
\text { vzorek }\end{array}$ & Klíčová zjištění & $\begin{array}{l}\text { Výzkumn } \\
\text { é nástroje } \\
\text { (u } \\
\text { empirick } \\
\text { é studie) }\end{array}$ & $\begin{array}{l}\text { Rok } \\
\text { vydání }\end{array}$ & Jazyk & $\begin{array}{l}\text { Počet } \\
\text { citačníc } \\
\text { h ohlasů } \\
\text { Google } \\
\text { Scholar }\end{array}$ & $\begin{array}{l}\text { Počet } \\
\text { citačníc } \\
\text { h ohlasů } \\
\text { WoS }\end{array}$ & $\begin{array}{l}\text { Počet } \\
\text { citační } \\
\text { ch } \\
\text { ohlasů } \\
\text { SCOP } \\
\text { US }\end{array}$ \\
\hline $\begin{array}{l}\text { Teacher } \\
\text { educators' } \\
\text { digital } \\
\text { competence }\end{array}$ & Norsko & $\begin{array}{l}\text { Teoreti } \\
\text { cká }\end{array}$ & & $\begin{array}{l}\text { Digitální kompetence se } \\
\text { staly jedním z pilířo } \\
\text { vzdělávání učitelů, hovoří } \\
\text { se o digitálním "bildung" a } \\
\text { celé vzdělávání a má } \\
\text { graduální charakter. Důraz } \\
\text { je kladen na kombinaci } \\
\text { teoretické a praktické } \\
\text { složky vzdělávání, které se } \\
\text { musí rozvíjet společně. }\end{array}$ & & 2014 & angličtina & 191 & 62 & 59 \\
\hline
\end{tabular}




\begin{tabular}{|c|c|c|c|c|c|c|c|c|c|c|}
\hline $\begin{array}{l}\text { Experts' } \\
\text { views on } \\
\text { digital } \\
\text { competence: } \\
\text { Commonalit } \\
\text { ies and } \\
\text { differences }\end{array}$ & $\begin{array}{l}\text { Nizozem } \\
\text { sko }\end{array}$ & $\begin{array}{l}\text { Empiric } \\
\text { ká }\end{array}$ & $\begin{array}{l}95 \\
\text { odborník } \\
\text { ů z } \\
\text { Evropy i } \\
\text { mimo ni }\end{array}$ & $\begin{array}{l}\text { Na tom, co jsou to digitální } \\
\text { kompetence nepanuje } \\
\text { paradigmatická shoda. } \\
\text { Současně je zřejmé, že } \\
\text { není možné je identifikovat } \\
\text { s prostým užíváním } \\
\text { techniky, byt' by bylo } \\
\text { časté. Mohou být vztaženy } \\
\text { na kognitivní nebo } \\
\text { znalostní úroveň. }\end{array}$ & $\begin{array}{l}\text { Delfská } \\
\text { metoda }\end{array}$ & 2013 & angličtina & 165 & 61 & 52 \\
\hline $\begin{array}{l}\text { Situated } \\
\text { learning and } \\
\text { teachers' } \\
\text { digital } \\
\text { competence }\end{array}$ & Norsko & $\begin{array}{l}\text { Teoreti } \\
\text { cká }\end{array}$ & & $\begin{array}{l}\text { Model se zaměřuje na čtyři } \\
\text { základní složky: základní } \\
\text { dovednosti v oblasti ICT, } \\
\text { didaktické dovednosti v } \\
\text { oblasti ICT, strategie učení } \\
\text { a "digital bildung". } \\
\text { Poslední položka se pak } \\
\text { vztahuje k bytí v digitální } \\
\text { společnosti, digitalizované } \\
\text { škole či jiné komunitě. }\end{array}$ & & 2008 & angličtina & 208 & 39 & 47 \\
\hline $\begin{array}{l}\text { Developmen } \\
\text { t of digital } \\
\text { competence } \\
\text { in secondary } \\
\text { education } \\
\text { teachers' } \\
\text { training }\end{array}$ & $\begin{array}{l}\text { Španělsk } \\
\text { o }\end{array}$ & $\begin{array}{l}\text { Empiric } \\
\text { ká }\end{array}$ & $\begin{array}{l}43 \\
\text { studentů } \\
\text { učitelství }\end{array}$ & $\begin{array}{l}\text { Studenti učitelství se } \\
\text { v digitálních kompetencích } \\
\text { hodnotí velice slabě. Škola } \\
\text { jim nedává dostatečné } \\
\text { nástroje pro formální } \\
\text { edukaci v této oblasti. }\end{array}$ & $\begin{array}{l}\text { Sebehodn } \\
\text { ocení dle } \\
\text { DigComp }\end{array}$ & 2018 & angličtina & 34 & 10 & 13 \\
\hline
\end{tabular}




\begin{tabular}{|c|c|c|c|c|c|c|c|c|c|c|}
\hline $\begin{array}{l}\text { A qualitative } \\
\text { exploration } \\
\text { of the EU } \\
\text { digital } \\
\text { competence } \\
\text { (DIGCOMP } \\
\text { ) } \\
\text { framework: } \\
\text { A case study } \\
\text { within } \\
\text { healthcare } \\
\text { education }\end{array}$ & $\begin{array}{l}\text { Velká } \\
\text { Británie }\end{array}$ & $\begin{array}{l}\text { Empiric } \\
\text { ká }\end{array}$ & $\begin{array}{l}5 \\
\text { akademi } \\
\text { ků, } 3 \\
\text { studenti, } \\
3 \\
\text { administ } \\
\text { rativní } \\
\text { pracovní } \\
\text { ci }\end{array}$ & $\begin{array}{l}\text { Respondenti se silně } \\
\text { opírají o kompetence } \\
\text { zaměřené na učení se, } \\
\text { zábavu a př́iem informací. } \\
\text { Naopak se ukazuje, že } \\
\text { sociální aspekty využitích } \\
\text { technologií a jejich širší } \\
\text { uchopení nebylo pro } \\
\text { zdravotníky tak významné. }\end{array}$ & $\begin{array}{l}\text { Rozhovor } \\
\text { y }\end{array}$ & 2014 & angličtina & 14 & 0 & 7 \\
\hline $\begin{array}{l}\text { Digital } \\
\text { competence: } \\
\text { A need for } \\
\text { university } \\
\text { teachers in } \\
\text { the } 21 \text { st } \\
\text { century }\end{array}$ & $\begin{array}{l}\text { Španělsk } \\
\text { o }\end{array}$ & $\begin{array}{l}\text { Empiric } \\
\text { ko- } \\
\text { teoretic } \\
\text { ká }\end{array}$ & & $\begin{array}{l}\text { Článek navrhuje vlastní } \\
\text { model př́ípravy učitelů, } \\
\text { který v jistém ohledu } \\
\text { kombinuje pohledy } \\
\text { DigCompEdu a } \\
\text { Krumsvika. }\end{array}$ & $\begin{array}{l}\text { Analýza } \\
\text { současné } \\
\text { ho stavu } \\
\text { škol }\end{array}$ & 2018 & $\begin{array}{l}\text { španělšti } \\
\text { na }\end{array}$ & 0 & 6 & 6 \\
\hline $\begin{array}{l}\text { Exploring } \\
\text { the } \\
\text { competency } \\
\text { gap of it } \\
\text { students in } \\
\text { Thailand: } \\
\text { The } \\
\text { employers' } \\
\text { view of an } \\
\text { effective } \\
\text { workforce }\end{array}$ & Thajsko & $\begin{array}{l}\text { Empiric } \\
\text { ká }\end{array}$ & $\begin{array}{l}49 \\
\text { organiza } \\
\text { cí }\end{array}$ & $\begin{array}{l}\text { Existují velké rozdíly mezi } \\
\text { očekáváním } \\
\text { zaměstnavatelů a tím, co } \\
\text { jsou schopny v kurikulu } \\
\text { zachytit univerzity ve } \\
\text { velké části digitálních } \\
\text { kompetencí. Text zajímavě } \\
\text { ukazuje, že existuje něco } \\
\text { jako neporozumění mezi } \\
\text { univerzitou a trhem v tom, } \\
\text { co je to profil absolventa, } \\
\text { respektive, jak vypadá } \\
\text { člověk připravený do } \\
\text { praxe. }\end{array}$ & $\begin{array}{l}\text { Dotazník } \\
\text { a } \\
\text { statistick } \\
\text { á analýza }\end{array}$ & 2017 & angličtina & 5 & 1 & 3 \\
\hline
\end{tabular}




\begin{tabular}{|c|c|c|c|c|c|c|c|c|c|c|}
\hline $\begin{array}{l}\text { Outlines for } \\
\text { science } \\
\text { digital } \\
\text { competence } \\
\text { of } \\
\text { elementary } \\
\text { school } \\
\text { students }\end{array}$ & $\begin{array}{l}\text { Slovinsk } \\
\text { o }\end{array}$ & $\begin{array}{l}\text { Teoreti } \\
\text { cká }\end{array}$ & & $\begin{array}{l}\text { Text popisuje tři roviny } \\
\text { digitální kompetence - } \\
\text { obecnou, obecnou } \\
\text { učitelskou a speciální } \\
\text { vědeckou zaměřenou na } \\
\text { konkrétní vědu. Každá ze } \\
\text { tř́ roviny je něčím odlišná. } \\
\text { Aby bylo dosaženo jejich } \\
\text { dostatečné kvality, } \\
\text { navrhují autoři studie } \\
\text { provádět externí certifikaci } \\
\text { učitelů. }\end{array}$ & & 2018 & angličtina & 2 & 0 & 2 \\
\hline $\begin{array}{l}\text { The } \\
\text { European } \\
\text { digital } \\
\text { competence } \\
\text { framework: } \\
\text { Contributio } \\
\text { n for its } \\
\text { comprehensi } \\
\text { on and } \\
\text { development }\end{array}$ & $\begin{array}{l}\text { Portugals } \\
\text { ko }\end{array}$ & $\begin{array}{l}\text { Teoreti } \\
\text { cká }\end{array}$ & & $\begin{array}{l}\text { Text se věnuje } \\
\text { myšlenkovým } \\
\text { východiskům Digcomp a } \\
\text { jeho možné praktické } \\
\text { implementaci v } \\
\text { Portugalském prostředí. }\end{array}$ & & 2017 & $\begin{array}{l}\text { portugalš } \\
\text { tina }\end{array}$ & 6 & 0 & 2 \\
\hline $\begin{array}{l}\text { The } \\
\text { kaleidoscope } \\
\text { of voices: An } \\
\text { action } \\
\text { research } \\
\text { approach to } \\
\text { informing } \\
\text { institutional } \\
\text { e-learning } \\
\text { policy }\end{array}$ & $\begin{array}{l}\text { Velká } \\
\text { Británie }\end{array}$ & $\begin{array}{l}\text { Empiric } \\
\text { ká }\end{array}$ & $\begin{array}{l}1 \\
\text { universit } \\
\mathrm{a}\end{array}$ & $\begin{array}{l}\text { Klíčové pro inovace ve } \\
\text { vzdělávání je jednak } \\
\text { rozvíjet kompetence } \\
\text { aktivně pracující s } \\
\text { digitálními nástroji, ale } \\
\text { také chápat dobře potřeby } \\
\text { většiny v dané instituci. }\end{array}$ & $\begin{array}{l}\text { Akční } \\
\text { výzkum }\end{array}$ & 2016 & angličtina & 7 & 5 & 2 \\
\hline
\end{tabular}




\begin{tabular}{|c|c|c|c|c|c|c|c|c|c|c|}
\hline $\begin{array}{l}\text { Digital } \\
\text { competence' } \\
\text { s } \\
\text { frameworks } \\
\text { in Europe: } \\
\text { An } \\
\text { approaching } \\
\text { to Spanish } \\
\text { and } \\
\text { Norwegian } \\
\text { framework }\end{array}$ & $\begin{array}{l}\text { Španělsk } \\
\text { o }\end{array}$ & $\begin{array}{l}\text { Teoreti } \\
\text { cká }\end{array}$ & & $\begin{array}{l}\text { Komparace DigComp, } \\
\text { Španělského a } \\
\text { Krumsvikova modelu } \\
\text { digitálních kompetencí. }\end{array}$ & & 2014 & angličtina & 3 & 0 & 2 \\
\hline $\begin{array}{l}\text { Digital } \\
\text { literacy, } \\
\text { digital } \\
\text { competence } \\
\text { and research } \\
\text { productivity } \\
\text { of educators }\end{array}$ & Filipíny & $\begin{array}{l}\text { Empiric } \\
\text { ká }\end{array}$ & $\begin{array}{l}\text { Akademi } \\
\text { ci - blíže } \\
\text { nezjištěn } \\
\text { ý počet }\end{array}$ & & $\begin{array}{l}\text { Statistick } \\
\text { é metody }\end{array}$ & 2019 & angličtina & 6 & 0 & 1 \\
\hline $\begin{array}{l}\text { Scenarios of } \\
\text { Technology } \\
\text { Enhanced } \\
\text { Learning } \\
\text { (TEL) and } \\
\text { Technology } \\
\text { Enhanced } \\
\text { Teaching } \\
\text { (TET) in } \\
\text { Academic } \\
\text { Education A } \\
\text { Forecast for } \\
\text { the Next } \\
\text { Decade and } \\
\text { its }\end{array}$ & Německo & $\begin{array}{l}\text { Teoreti } \\
\text { cká }\end{array}$ & & $\begin{array}{l}\text { Porovnání čtyř možných } \\
\text { scénárỏ vývoje vzdělávání } \\
\text { a jeho dopady na učitelské } \\
\text { kompetence. Pracuje s } \\
\text { DigCompEdu }\end{array}$ & & 2019 & angličtina & 2 & 0 & 1 \\
\hline
\end{tabular}




\begin{tabular}{|l|l|l|l|l|l|l|l|l|l|}
\hline $\begin{array}{l}\text { Consequenc } \\
\text { es for } \\
\text { Teaching } \\
\text { Staff. }\end{array}$ & & & & & & & \\
\end{tabular}

Tab. ̌́. 2. prehled analyzovaných studii. 